\title{
THE INFLUENCE OF CLIMATE ON THE DEVELOPMENT OF AGRICULTURAL WATER SUPPLIES IN CANTERBURY
}

T. S. HARDing

(M.Sc., University of Canterbury)

This study evaluates the influence of climate in the development of agricultural water supplies in Canterbury. A discussion of 'the historical and spatial occurrence is presented, as well as a description of the suitability of the region to such development.

The influence of climate is assessed by the provision of a measure of agriculttiral drought. This measure is achieved by the utilization of the concept of potential evapotranspiration in the calculation of the soil water deficits. Description of the spatial variation of the annual soil water deficit is provided. The annual soil water deficit is used in statistical analysis against various expressions of interest in irrigation development, and also against actual development in terms of the area border-dyked each season.

It is concluded that there is indeed a tendency for climate, particularly drought, to influence the development of agricultural water supplies. It is, however, difficult to indicate its precise influence owing to the involvement of other factors. 